\title{
REVIEW OF NATURE-INSPIRED OPTIMIZATION ALGORITHMS APPLIED IN CIVIL ENGINEERING
}

\author{
Scientific paper / Znanstveni rad \\ Dino Obradović \\ (Received: 7 November 2018; accepted: 10 December 2018) \\ University of Osijek, Faculty of Civil Engineering and Architecture Osijek, mag.ing.aedif. \\ Corresponding author: dobradovic@gfos.hr

\begin{abstract}
Nature has always been an example of perfection and inspiration. In nature, everything has reasons why it is happening exactly the way it does. Nature-inspired optimization algorithms have become a rapidly growing area of research in all areas of life. Ant colonies find the shortest path to food, the evolution of the living world shows adaptation to the world around it. For example, bees find the optimal path to food and back to the hive. Optimization algorithms contribute significantly to solving many complex issues and achieving optimal results. This research paper outlines nature-inspired optimization algorithms, such as ant colonies, artificial immune systems, artificial neural networks, flocks of bats, bee swarms, firefly algorithms, genetic algorithms, and particle swarms. The purpose of this brief overview is to provide an easy-to-understand list of the basic features of the most common nature-inspired optimization algorithms as well as the potential applications of the aforementioned algorithms in civil engineering.
\end{abstract}

Keywords: algorithm; civil engineering; heuristics; nature-inspired; optimization

\section{PREGLED OPTIMIZACIJSKIH ALGORITAMA NADAHNUTIH PRIRODOM, PRIMIJENJENIH U GRAĐEVINARSTVU}

Sažetak: Priroda je oduvijek bila primjer savršenosti i nadahnuća. Sve što se događa u prirodi, događa se na taj način s određenim razlogom. Prirodom nadahnut optimizacijski algoritmi postaju brzo rastuće područje istraživanja u svim područjima života. Kolonije mrava pronalaze najkraći put do hrane, evolucija živog svijeta pokazuje prilagođavanje svijetu koji ga okružuje, pčele pronalaze optimalan put do hrane i natrag do košnica itd. Optimizacijski algoritmi daju veliki poticaj za rješavanje mnogo složenih problema te pronalaženje optimalnog rezultata. U ovom radu, ukratko će se prikazati prirodom inspirirani optimizacijski algoritmi kao što su kolonije mrava, umjetni imunološki sustav, umjetne neuronske mreže, jato šišmiša, roj pčela, algoritam krijesnica, genetski algoritam i roj čestica. Svrha ovog kratkog pregleda je dati lagano shvatjivi popis te osnovne karakteristike najčešćih optimizacijskih algoritama koji imaju nadahnuće u prirodi te moguću primjenu prethodno navedenih algoritama u građevinarstvu.

Ključne riječi: algoritam; građevinarstvo; heuristike; prirodom nadahnuti; optimizacija

Obradović, D 


\section{INTRODUCTION}

Nature is a great source of inspiration in the development of intelligent systems, and it also enables the solution of complex problems [1]. This is why so many researchers are attracted to nature. The algorithms developed with inspiration from nature are known as nature-inspired algorithms. Nature-inspired algorithms (also known as biological systems) have become very popular because of their ability to adapt to any changing environment [2]. Further, nature-inspired algorithms have gained popularity in the optimization of complex problems [3] because optimization problems in the real world are often very challenging to solve [4]. An optimization problem consists of maximization or minimization of a function in relation to a set, which represents the possibility of available choices in a given situation. The function allows the comparison of different choices, so that one can decide which choice might be the best [5].

To solve optimization problems that are very difficult to solve, complex and "uzzy" (they cannot be wellformulated mathematically) [6] heuristic and metaheuristic techniques (algorithms) are used. Heuristic techniques can be used to solve a wide variety of optimization problems [7]. The term "heuristic technique" implies any technique that is used to find a specific acceptable solution to the observed problem. However, the solution found does not have to be optimal, but must be permissible, and it is considered that such a technique can find a solution much quicker than if the exact solution is sought using some other technique. Moreover, if there is more than one solution, heuristic methods are used to find only some of these solutions, but not all possible solutions. Hence, heuristic methods seek the balance between optimality, completeness, and accuracy of a solution on one hand and the time of execution on the other hand. The quality of a specific heuristic method used depends on the abovementioned factors [8]. Heuristic methods that are not specially designed for a particular problem, but are, with certain adaptations, applicable to a large number of problems, are called metaheuristic methods [8]. In addition, as extensions to main heuristic methods, hyperheuristic and stochastic techniques are known [7]. The term "metaheuristics" was first coined by Glover in 1986 [9].

A metaheuristic is a high-level problem-independent algorithmic framework that provides a set of guidelines or strategies to develop heuristic optimization algorithms. The term is also used to refer to a problem-specific implementation of a heuristic optimization algorithm according to the guidelines expressed in such a framework [10]. Most heuristic and metaheuristic methods (if not all of them) are listed in the paper authored by Venkrbec, Galić, and Klanšek [7] and in the paper authored by Fister et al. [4] Therefore, for the purpose of further study, it is advisable to read the two aforementioned papers. The described heuristic and metaheuristic methods are used to solve real-world optimization problems, the so-called NP-hard problems. To solve such problems, optimization techniques should be used, though there is no guarantee that the optimal solution can be obtained. In fact, for NPproblems, there are no efficient algorithms at all [4].

Optimization is applicable and useful in many areas of human life. Obviously, the goal of an optimization can vary, such as minimizing energy consumption and costs, maximizing profit, minimizing the project completion time, minimizing risk, maximizing the effects of a machine. As resources, time, and money are always limited in real life, our job is to find solutions that optimally use these valuable resources under different conditions [11].

Generally, an optimization algorithm is an iterative process, starting from some initial assumption. After a certain (sufficiently large) number of iterations, the solution begins to converge towards a stable solution, ideally the optimal solution of the observed problem [12-14]. In essence, an algorithm is a set of symbols and a general procedure, which explains how to solve a task stepwise. Many algorithms are of iterative nature. Correct steps and procedures depend on the algorithm used and the area of interest [11]. Among nature-inspired algorithms, a special type of algorithm has been developed with inspiration by swarm intelligence (SI). Algorithms based on SI are among the most popular ones [4]. SI is the collective behavior of natural or artificial decentralized, self-organizing systems. SI systems are usually made of populations of simple agents (particles) that communicate with each other and with their environment [15]. To find the optimum solution in the solution space for each particle, particle swarm optimization (PSO) allows the particles to communicate; each particle that is a candidate for the solution seeks an optimal solution simultaneously using mutual interaction and cognitive knowledge [16-18].

The rest of this paper provides the selected nature-inspired optimization algorithms, some of which are more or less known. The main objective of this paper is to provide a list of some (more frequent) optimization algorithms, their possible application in civil engineering, and the most basic characteristics thereof, without elaborating on any of them, because the length of such a paper would exceed the expected length of a review paper. Moreover, one

Obradović, D 
of the main goals of this paper is to familiarize potential users with optimization algorithms and to arouse their interest encouraging them to use the algorithms to a greater extent as compared to their present use.

\section{SELECTED NATURE-INSPIRED OPTIMIZATION ALGORITHMS}

\subsection{Ant colony optimization}

Ant colony optimization (ACO) is a method inspired by natural systems $[19,20]$. The ACO algorithm is based on the hypothetical behavior of an ant collective when the ants are looking for food [21-23]. If there are no available traces of pheromones, the ants move randomly. However, if the pheromones are present, the ants follow the trace of the pheromones [24]. During their search for food, the ants secrete pheromones in order to mark their path, but the pheromones evaporate over time. In nature, ants use the shortest path to reach their colony as quick as possible, so this (the shortest, i.e., the fastest) path is marked by a higher concentration of pheromones. This path serves as bait for other ants, and over time all ants from a specific colony choose this optimal (shortest) path [2123]. The amount of released pheromones is proportional to the quality of the solution, which affects the probability that other ants will use the components (portions) of that solution in creating their own, personal solution. This contributes to the global search for a solution in the ACO algorithm [25].

The key to the success of the ACO is in its construction of new solutions [26]. The ACO algorithm was first introduced by Dorigo et al. in the 1990's [27, 28]. ACO algorithms are shown to be effective problem-solving strategies for a wide range of problem domains, including multiple-objective optimization [29].

\subsection{Artificial immune system}

The natural immune system is a complex system adapted to the identification of pathogens, foreign microorganisms. It protects the body from various foreign pathogens such as bacteria or viruses [30-32]. One of the main purposes of the immune system is to keep the organism healthy [33]. An artificial immune system (AIS) appeared in the 1990's as a new branch in computational (artificial) intelligence. AlSs are inspired by immunology, the immune function, and principles observed in nature [32, 34, 35]. AlSs mimic biological principles of clone generation, proliferation, and maturation. The main steps of AISs based on the clonal selection principle are the activation of antibodies, proliferation, and differentiation on the encounter of cells with antigens, maturation by carrying out the affinity maturation process, elimination of old antibodies to maintain the diversity of antibodies and to avoid premature convergence, and selection of those antibodies whose affinities with the antigen are greater [36].

The field of AISs is a diverse area of research, which bridges the disciplines of immunology and engineering. AIS algorithms are typically developed from the abstraction of immune system theories, processes, and agents, and they are applied to a wide variety of engineering applications including computer security, fault tolerance, data mining [37] and optimization [37-39].

\subsection{Artificial neural network}

An artificial neural network (ANN) can be described as a massive, parallel, distributed data-processing system that consists of simple elements and has a natural tendency to store experiential knowledge, which can be used later, and is similar to the brain in the way it acquires and stores knowledge $[40,41]$. The study of neural networks was started by the publication by McCulloch and Pitts [42]. In their work [42], they created a computational model for neural networks based on mathematics and algorithms called threshold logic. Single-layer networks, with threshold activation functions, were introduced by Rosenblatt. These types of networks are called perceptrons. In the 1960's, it was experimentally shown that perceptrons could solve many problems, but many problems, which did not seem to be more difficult, could not be solved. Neural networks make an attempt to simulate the human brain [43].

In 1986, a group of three authors described a new learning procedure, back-propagation, for networks of neuron-like units [44]. ANNs offer an alternative to classic computation for the real-world problems that use natural knowledge (which may be uncertain, imprecise, inconsistent, and incomplete) and for which the development of a conventional program that covers all possibilities and eventualities is unlikely or at least very laborious and expensive [45]. 


\subsection{Bat algorithm}

Bat algorithms (BAs) belong to a class of SI algorithms [46, 47]. The BA was developed by Yang [48, 49]. BAs are based on the echolocation behavior of microbats $[49,50]$ with varying pulse rates of emission and loudness. $A$ multi-objective BA was developed to solve design optimization problems such as welded beam design problems [51]. Bats use a type of sonar, the so-called echolocation, to detect their prey, avoid obstacles, and locate cracks where they live in the dark. Bats emit a very loud sound pulse and listen for the echo that bounces back from the surrounding objects [51,52]. During roaming, microbats emit short pulses; however, when a potential prey is nearby, their pulse emission rates increase and the frequency is tuned up [49]. They have the ability to automatically adjust the wavelength or frequency of the pulses, and can automatically control the degree of pulse transmission depending on the distance between them and the prey $[52,53]$. The increase of the frequency, namely frequencytuning, together with the speedup of the pulse emission shortens the wavelength of echolocations and thus increases the detection accuracy [49].

BAs are successfully applied to a number of very different problems such as large-scale optimization problems [54, 55], multi-objective optimization [51], economic load and emission dispatch problems, data mining [54], etc.

\subsection{Bee colony optimization}

Teodorović et al. developed a method of bee colony optimization (BCO) [56-58]. The basic idea of BCO is to create a colony of artificial bees that will be able to solve difficult combinatorial optimization problems effectively. A swarm of artificial bees is flying in the space of possible solutions, seeking possible, favorable solutions. Each bee generates one solution to the problem. In order to find good solutions, artificial bees cooperate and exchange information $[59,60]$. Using collective knowledge and sharing information between themselves, bees concentrate on better solution spaces and slowly leave worse solutions [61]. Artificial bees create and improve their solutions together [59]. The BCO algorithm, based on the principles of SI [62, 63], provides excellent, promising results for solving complex engineering problems [57].

BCO has many applications in several different fields. One of the most interesting applications is the training of neural networks [64]. BCO was also used by some researchers for solving discrete optimization problems in the design of trusses [64, 65], for minimizing the weight of lattice structures [56], etc.

\subsection{Firefly algorithm}

In the firefly algorithm (FA or also called FFA), the objective function of a given optimization problem is based on differences in light intensity. It helps fireflies to move towards brighter and more attractive locations in order to obtain optimal solutions [66]. In the FA, there are two important variables: light intensity and attractiveness [67]. The movement of a firefly is determined by a brighter firefly (than itself) to which it is attracted $[67,68]$.

Multiple fireflies are randomly distributed in the whole search space, and all fireflies have their light intensity, corresponding to the fitness value of the optimization problem. Then each individual flies following the firefly with higher light intensity in its visual range. After multi-iterations, all individuals gather around the best firefly, which represents the final optimization [69]. The FA is a swarm-based metaheuristic algorithm introduced by Yang [7072].

\subsection{Genetic algorithm}

The genetic algorithm (GA) is an algorithm based on natural selection and mechanisms of population genetics [73]. It was proposed (invented) by Holland in the early seventies [74, 75]. The GA is a stochastic technique to find a solution that mimics the principles of natural genetics $[76,77]$. The GA is inspired by biological evolution, Charles Darwin's theory of natural evolution [78], which uses propagation, random mutation, genetic diversity, and natural selection [79]. This algorithm reflects the process of natural selection where the best individuals are selected for breeding to give offspring in the next generation [72].

The advantage of the GA compared to conventional solution-searching techniques is that it starts with an initial set of random solutions of the named populations. Each individual in the population is called a chromosome, and represents a solution to a problem [77]. 


\subsection{Particle swarm optimization}

Particle swarm optimization (PSO) is one of the most popular nature-inspired optimization algorithms because of its simplicity and ease of use [80, 81]. This algorithm is inspired by the movement of birds and fish in their groups, i.e., the social behavior of feeding birds and fish $[82,83]$. PSO solves optimization problems through a series of searches performed by a group of individuals [82, 84]. In PSO, potential solutions, called particles, fly through the space, in which a solution to a problem is searched by following the current optimal particle [85].

In nature, there is always a leader (the main bird or fish) that leads a flock of birds or fish. PSO is successfully applied in many areas such as optimization of functions, training of ANNs, system control, optimization of time and cost in project execution, etc. [85].

Table 1 lists some of the main characteristics (including the algorithm name and its abbreviation, the source of inspiration, and its authors, year, and reference) of the aforementioned nature-inspired algorithms.

Table 1 Short list of the selected nature-inspired algorithms in alphabetical order

\begin{tabular}{|c|c|c|c|c|}
\hline Algorithm & Inspiration & Authors & Year & Reference \\
\hline Ant colony optimization, ACO & behavior of ant colonies & $\begin{array}{l}\text { Colorni, Dorigo, and } \\
\text { Maniezzo }\end{array}$ & 1991 & [28] \\
\hline Artificial immune system, AIS & $\begin{array}{l}\text { human immune system } \\
\text { function }\end{array}$ & Kephart & 1994 & [86] \\
\hline Artificial neural network, ANN & $\begin{array}{c}\text { biological neural networks and } \\
\text { brain }\end{array}$ & McCulloch and Pitts & 1943 & [42] \\
\hline Bat algorithm, BA & $\begin{array}{c}\text { echolocation behavior of } \\
\text { microbats }\end{array}$ & Yang & 2010 & [48] \\
\hline Bee colony optimization, BCO & bees' foraging principles & Lučić and Teodorović & 2001 & {$[58]$} \\
\hline Firefly algorithm, FA or FFA & $\begin{array}{l}\text { flashing characteristics of } \\
\text { fireflies }\end{array}$ & Yang & 2010 & [70] \\
\hline Genetic algorithm, GA & $\begin{array}{c}\text { natural mechanisms of } \\
\text { population genetics }\end{array}$ & Holland & 1975 & {$[75]$} \\
\hline Particle swarm optimization, PSO & $\begin{array}{c}\text { social behavior of feeding birds } \\
\text { and fish }\end{array}$ & $\begin{array}{l}\text { Kennedy and } \\
\text { Eberhart }\end{array}$ & 1995 & [82] \\
\hline
\end{tabular}

\section{APPLICATION OF NATURE-INSPIRED OPTIMIZATION ALGORITHMS IN CIVIL ENGINEERING}

The applications of nature-inspired optimization algorithms in civil engineering are widespread. Civil engineering is a professional engineering discipline, which deals with the design, construction, and maintenance of physical and naturally built environments, including houses, skyscrapers, canals, bridges, dams, airports, sewerage systems, pipelines, roads and railways, schools, hospitals, etc. [87, 88].

This section will provide a brief overview of some potential applications of nature-inspired optimization algorithms in the field of civil engineering. The names of specific algorithms, studied problems, main findings and conclusions, and their origin are shown in alphabetical order (of algorithms) in Table 2.

To keep the overview as recent as possible and of an appropriate length (not too long), it will be limited to the time period from 2010 to onward. In addition, approximately five applications will be provided for each natureinspired algorithm found in the available literature. 
Table 2 List of the selected nature-inspired algorithms and some of applications in civil engineering

\begin{tabular}{|c|c|}
\hline Algorithm & Studied problem \\
\hline & $\begin{array}{l}\text { optimal design of storm sewer } \\
\text { networks }\end{array}$ \\
\hline & efficient routing of piping networks \\
\hline $\begin{array}{l}\text { 운 } \\
\text { ¿ } \\
\text { E }\end{array}$ & $\begin{array}{l}\text { performance-based optimal } \\
\text { seismic design offrame structures }\end{array}$ \\
\hline 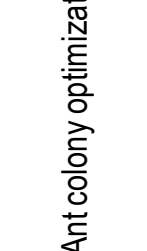 & $\begin{array}{l}\text { determination of the ultimate } \\
\text { bearing capacity of shallow } \\
\text { foundations on granular soil } \\
\text { solving the stochastic time-cost } \\
\text { trade-off optim ization problem }\end{array}$ \\
\hline
\end{tabular}

decision-support system for construction time-cost optimization

The applicability and efficiency of ACO in the studied problem are excellent. The used methods are shown to be very effective in locating the optimal solution and in terms of the convergence characteristics of the resulting algorithms.

ACO provides a powerful means of performing network optimization through the shortest-path calculations, as it is able to construct the shortestpath solutions efficiently. Moreover, ACO exhibits quick convergence to the final solution.

The results obtained indicate that the $\mathrm{ACO}$ algorithm can find the optimum seismic design of structures successfully.

The algorithm will find wide application in the calculation of the ultimate bearing capacity of foundations.

The model attempts to minimize the time and cost of a project as two objectives. The results show that the algorithm is adequately reliable.

The results show that the model based on the ant colony system techniques can generate better solutions without utilizing excessive computational resources. The model provides an efficient means to supportplanners and managers in making better time-cost decisions efficiently.

The optimization results showed that the proposed optimization of the pumping schedule in water distribution networks heuristic approaches considerably improved the quality of solutions and enhanced the navigation of the optimization process.

The proposed algorithm was tested on 162

flexible job-shop scheduling problem benchmark problems and results showed that the presented algorithm is effective in overcoming those problems.

project scheduling problem under resource constraints

The computational results show that the proposed algorithm has competitive results of solving real-world problems compared to the existing benchmark algorithms.

analysis of structural integrity of a building

structural health monitoring (SHM)

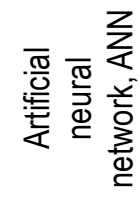

methodology for determining the execution time and cost of earthworks
The results obtained using the presentmethod are efficient, robust, and accurate. The paper presented a new method to analyze failures in structures.

The high success rate shown by this approach has greatpotential for SHM tasks. The results showed that the proposed AIS could reach a relatively high accuracy with limited training antigens.

The results presented in the paper confirm the fact that trained ANNs can be used in designing earthwork organization in construction to determ ine the time necessary to carry outearthworks and to calculate

Obradović, D 
determination of the ultimate bearing capacity of shallow foundations on granular soil

damage identification in civil engineering structures

energy analysis of a building

measuring and predicting construction-labor productivity

calibration of a microsimulation traffic model

capacitated vehicle routing problem (CVRP)

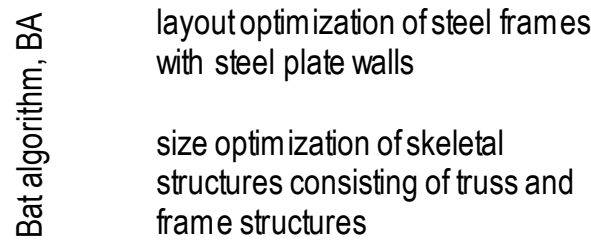

optimum design oflarge-scale truss structures

production scheduling for dispatching ready-mixed concrete (RMC) trucks

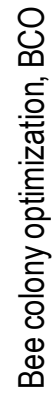

job-shop scheduling

problems

transit network design
The algorithm will find wide application in the calculation of the ultimate bearing capacity of foundations.

Compared with modal-based approaches, the used method requires much less post-processing of the recorded data. Especially, there is no need for manual processing, which makes the developed method more suitable for on-line health monitoring.

Results presented in this paper confirm the potential of ANNs as a design tool in many areas of building service engineering.

A model for measuring and predicting labor productivity in construction projects was developed by utilizing ANNs. The developed model was successful.

Presented results clearly show that a neural network is notan alternative to a microsimulation model. The neural network accurately predicted the traveling time, but not the queue parameters.

In this paper, a hybrid BA with path relinking for solving the CVRP was presented. Results show that the methodology is able to provide fine-quality solutions, which can compete with the ones provided by some exact and heuristic approach.

The results reveal the effectiveness of the proposed method for optimization of steel frames with steel plate walls.

Results presented in the paper show the suitability and efficiency of the presentalgorithm for optimal design of skeletal structures.

The paper presents an improved BA for optimizing large-scale structures. The capability of the algorithm is examined by comparing the resulting design parameters and structural weight with those of other methods from the literature.

The experimental results showed that the $\mathrm{BCO}$ approach can quickly generate efficient and flexible solutions to dispatch RMC trucks. Furthermore, the obtained results had higher quality solutions and faster com putational time than those obtained from the conventional approaches.

In this study, three modifications of $B C O$ are proposed, i.e., global evolution of some bees, dynamic parameters of the colony, and special treatment of the bestbee. The com puter simulation shows that the modified $\mathrm{BCO}$ performs quite better than the BCO for some job-shop scheduling problems.

The numerical experiments are performed on known benchmark problems. The approach, based on the $\mathrm{BCO}$ algorithm, is competitive with other approaches in the literature, and it can generate high-quality solutions. 
optimal design of truss structures

determining the optimum design of tower-shaped structures

optimization of queueing systems

눈

shape and size optimization of truss structures considering dynamic constraints

minimum weight design of newgeneration steel beams with sinusoidal openings

optimum cost of prestressed and reinforced concrete beams

optimization model for generating optimal schedules for repetitive projects

optimization design of high-

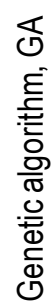

mult-objective optimization for scheduling a multi-storey building

construction project schedule
Numerical results indicate the robustness and efficiency of the proposed method in the optimum design of truss structures.

[110]

This method is effective in improving the convergence and also suitable for expensive optimization tasks such as large-scale structures. Three tower structures are selected to evaluate the performance of the algorithm. The results are better than other results proposed in the literature and confirm the validity of the proposed algorithm.

In this paper authors have tested FFA to the multiobjective maximization problem of cost function.

The FFA is a very powerful technique used to solve the problems of queueing system optimization.

FFA could find the optimal solution in a relatively shortcomputational time. For the tested examples, considering the same number of iterations, harmony search (HS) found the optimal solution in a slightly shorter time than FFA; however, in all cases, FFA found solutions slightly better than HS.

The results obtained by the application of firefly search algorithms demonstrate that new-generation sinusoidal steel beams produce a more cost-effective solution than other two beams as a result of their sleek, transparent, and flexible geometry, and they increase the efficacy of the relation capacity.

The comparison showed that the GA models were efficient in moving towards the beam optimum cost

A GA optimization model was developed for generating optimal schedules for repetitive projects.

This developed model is capable of offering valuable support to project team members in minimizing the overall cost of the project.

The GA could reduce the cost, save the energy, and provide better use value in the engineering practice.

It is concluded that the GA can be effectively used in the overall costoptimization of PC bridges.

The developed model enables construction planners to generate, from a set of feasible alternatives, optimal/near-optimal construction plans that minimize project duration, number of synchronized crews, and crew work interruptions. The transparency of the model and its versatile performance will hopefully encourage project managers to utilize it in the planning of repetitive projects.

In this paper, the authors demonstrate a novel approach of retrieving enough information from the building information model (BIM) of a projectand then develop construction sequencing for the installation of the projectelements.

Obradović, D 
The evaluation indicates that the proposed model

multi-objective construction site layoutplanning

structural truss mass optimization on size and shape with dynamic constraints

beam-slab layoutdesign problems

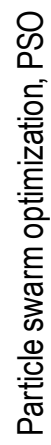

optimum design of unbraced steel frames to load and resistance factor design, American Institute of Steel Construction

determination of optimum time and costs

PSO-trained neural network for structural failure prediction of multistoried reinforced concrete (RC) buildings provides effective and rational solutions, in response to decision parameters and problem constraints, and that it results in more robustlayout planning than previous methods both qualitatively and quantitatively.

The results show that the particle swarm algorithm performed similar to other methods and even better in some cases.

The results from the example problem show the validity of the proposed algorithm. PSO can be a good alternative to the GA for solving the beam-slab layout design problem.

The efficiency of the algorithm is demonstrated considering a number of design examples, and it is satisfactory.

The PSO method can be successfully used for optimizing the realization of construction projects. The use of this method is recommended for optimization of global critical path diagrams for projects with smaller number of project-significant activities.

The work proposed a PSO-based approach to train a neural network (NN). PSO is employed to find the weight vector with the minimum root-mean-square error for the NN. The experimental results established the dominance of the proposed model for detecting the structural status of a multistoried RC building structure.

\section{SUMMARY AND CONCLUSION}

In this paper, the following optimization algorithms are briefly presented: ACO, AIS, ANN, BA, BCO, FFA, GA, and PSO. The purpose of an optimization is to find the best, optimal, solution to a specific observed problem, meaning a solution that will mostly satisfy the conflicting objectives. Nature-inspired optimization algorithms help to solve many complicated problems we face in real life. The common feature of all the aforementioned algorithms is that they are inspired by the behavior of the living world in nature, such as ants and bees, which find the shortest path to food and back to the nest, and then the functioning of the immune system, etc.

In the above-mentioned work (Section 2), the intention was to explain the basic concept of the optimization algorithms as briefly as possible, whereas for the further study, it is recommended to use the references listed in the bibliography section at the end of this paper. Section 3 provides an overview of the potential applications of nature-inspired algorithms in civil engineering. Papers related to the selected algorithms, found in the period from 2010 until now, are briefly presented. As they clearly show, each subsequent year brought new metaheuristics, and the existing metaheuristics are improved every year. However, it is important to emphasize that the development and improvement of metaheuristics come with the necessity to preserve the simplicity of their operational principles. One of the aims of this paper is to fill in the void that is present in the literature regarding the application of natureinspired algorithms in civil engineering.

In addition, the purpose of this overview is to inform the readers about nature-inspired optimization algorithms and to arouse their interest in further research of this topic. The potential users should be more thoroughly introduced into nature-inspired algorithms and their potential applications, not only in the field of civil engineering, but in all areas of human activity. Artificial intelligence and the related technologies (including optimization 
algorithms) are changing every day, and as computers become more popular and more advanced, the use of optimization algorithms is expected to increase in all areas of human life, as well as in civil engineering.

\section{References}

[1] Zang, H.; Zhang, S.; Hapeshi, K. 2010: A Review of Nature-Inspired Algorithms, Journal of Bionic Engineering, 7 (Suppl. 4), pp. S232-S237, https://doi.org/10.1016/S1672-6529(09)60240-7

[2] Chalotra, S.; Sehra, K. S.; Sehra, S. S. 2015: An Analytical Review of Nature Inspired Optimization Algorithms, International Journal of Science Technology \& Engineering, 2 (3), pp. 123-126

[3] Luthra, l.; Chaturvedi, K. S.; Upadhyay, D.; Gupta, R. 2017: Comparative study on nature inspired algorithms for optimization problem, International Conference on Electronics, Communication and Aerospace Technology, ICECA 2017, Coimbatore, India, pp. 143-147, https://doi.org/10.1109/ICECA.2017.8212781

[4] Fister, I. Jr.; Yang, X-S.; Fister, I.; Brest, J.; Fister, D. 2013: A Brief Review of Nature-Inspired Algorithms for Optimization, Elektrotehniški vestnik, 80 (3), pp. 116-122

[5] Sapienza Universita di Roma, Optimization problems, Chapter 1, http://www.dis.uniroma1.it $\sim$ palagi/didattica/sites/default/files/optimization_problems.pdf, $\quad$ Accessed 19 September 2018

[6] Dvornik, J. 2003: Numerical, symbolic and heuristic methods, Građevinar, 55 (10), pp. 575-582, (in Croatian)

[7] Venkrbec, V.; Galić, M.; Klanšek, U. 2018: Construction process optimisation - review of methods, tools and applications, Građevinar, 70 (7), pp. 593-606, https://doi.org/10.14256/JCE.1719.2016

[8] Stanojević, S. P. 2016: Exact and metaheuristic methods for solving NP-hard location problems, PhD Thesis, University of Belgrade, Faculty of Mathematics, Beograd (in Serbian)

[9] Glover, F. 1986: Future paths for integer programming and links to artificial intelligence, Computers \& Operations Research 13 (5), pp. 533-549., https://doi.org/10.1016/0305-0548(86)90048-1

[10] Sörensen, K. 2015: Metaheuristics-the metaphor exposed, International Transactions in Operational Research, 22 (1), pp. 3-18, htps://doi.org/10.1111/itor.12001

[11] Yang, Y.-S: 2014: Nature-Inspired Optimization Algorithms, Elsevier inc., Chapter 1, Introduction to Algorithms, pp. 1-21, http://dx.doi.org/10.1016/B978-0-12-416743-8.00001-4

[12] Koziel, S.; Yang X.-S. 2011: Computational Optimization, Methods and Algorithms, Springer, Germany

[13] Yang, X.-S. 2010: Engineering Optimisation: An Introduction with Metaheuristic Applications, John Wiley \& Sons inc., Hoboken, New Jersey

[14] Yang, Y.-S. 2014: Nature-Inspired Optimization Algorithms, Elsevier inc., Chapter 2 -Analysis of Algorithms, pp. 23-44, https://doi.org/10.1016/B978-0-12-416743-8.00002-6

[15] Zhang, Y.; Agarwal, P.; Bhatnagar, V.; Balochian, S.; Yan, J. 2013: Swarm Intelligence and Its Applications, The Scientific World Journal, 2013, pp.1-3, http://dx.doi.org/10.1155/2013/528069

[16] Thida, M.; Eng, H.-L.; Monekosso, N. D.; Remagnino, P. 2013: A particle swarm optimisation algorithm with interactive swarms for tracking multiple targets, Applied Soft Computing, 13 (6), pp. 3106-3117, https://doi.org/10.1016/j.asoc.2012.05.019

[17] Parsopoulos, K. E.; Vrahatis, M. N. 2002: Recent approaches to global optimisation problems through Particle Swarm Optimisation, Natural Computing 1 (2-3), pp. 235-306, https://doi.org/10.1023/A:1016568309421

[18] Poli, R. 2008: Analysis of the publications on the applications of particle swarm optimisation, Journal of Artificial Evolution and Applications, 2008 (4), pp. 1-10, http://dx.doi.org/10.1155/2008/685175

[19] Tang, K.; Xie, L.; Li, G. 2017: A multiple classifier system based on Ant-Colony Optimization for Hyperspectral image classification, Journal of Physics: Conference Series, 787, pp. 1-10, https://doi.org/10.1088/1742$6596 / 787 / 1 / 012011$

[20] Dorigo, M.; Birattari, M.; Stüzle, T. 2006: Ant Colony Optimization, Artificial Ants as a Computational Intelligence Technique, Université Libre de Bruxelles, IRIDIA - Technical Report Series, Technical Report No. TR/IRIDIA/2006-023

[21] Pessoa, M. C.; Ranzan, C., Trierweiler, F. L.; Trierweiler, O. J. 2015: Development of Ant Colony Optimization (ACO) Algorithms Based on Statistical Analysis and Hypothesis Testing for Variable Selection, 48 (8), 9 th

Obradović, D 
IFAC Symposium on Advanced Control of Chemical Process ADCHEM 2015, Whister, Canada, pp. 901-905, https://doi.org/10.1016/j.ifacol.2015.09.084

[22] Allegrini, F.; Olivieri, A. C. 2011: A new and efficient variable selection algorithm based on ant colony optimization. Applications to near infrared spectroscopy/partial least-squares analysis, Analytica chimica acta, 699 (1), pp. 18-25, https://doi.org/10.1016/j.aca.2011.04.061

[23] Li, B.; Wang, L.; Song, W. 2008: Ant Colony Optimization for the Traveling Salesman Problem Based on Ants with Memory, Fourth International Conference on Natural Computation, Jinan, China, pp. 496-501, https://doi.org/10.1109//CNC.2008.354

[24] Cordon, O.; Herrera, F., Stüzle, T. 2002: A review on the Ant Colony Optimization Metaheuristic: Basis, Models and New Trends, Mathware \& soft computing, IX (2-3), pp. 1-35, http://hdl.handle.net/2099/3624, Accessed 19 September 2018

[25] Salama, M. K.; Freitas, A. A. 2013: Learning Bayesian network classifiers using ant colony optimization, Swarm Intelligence, 7 (2-3), pp. 229-254, https://doi.org/10.1007/s11721-013-0087-6

[26] Ojha, K. V.; Abraham, A.; Snášel, V. 2014: ACO for Continous Function Optimization: A Performance Analysis, 14th International Conference on Intelligent Systems Design and Applications, Okinawa, Japan, https://doi.org/10.1109/ISDA.2014.7066253

[27] Dorigo, M.; Di Caro, G.; Gambardella, M. L. 1999: Ant algorithms for discrete optimization, Artificial Life, 5 (2), pp. 137-172, https://doi.org/10.1162/106454699568728

[28] Colorni, A., Dorigo, M., Maniezzo, V. 1991: Distributed Optimization by Ant Colonies, Proceedings of the first European conference on artificial life: Paris, France; pp. 134-142.

[29] Angus, D.; Woodward, C. 2009: Multiple objective ant colony optimisation, Swarm Intelligence, 3 (1), pp. 69 85, https://doi.org/10.1007/s11721-008-0022-4

[30] Dasgupta, D. 2002: Special Issue on Artificial Immune Systems, IEEE Transactions on Evolutionary Computation 6 (3), pp. 225-226.

[31] Bagheri, A.; Zandieh, M.; Mahdavi, I. Yazdani, M. 2010: An artificial immune algorithm for the flexible job-shop scheduling problem, Future Generation Computer Systems, 26 (4), pp. 533-541, https://doi.org/10.1016/j.future.2009.10.004

[32] Basu, M. 2011: Artificial immune system for dynamic economic dispatch, Electrical Power and Energy Systems, 33 (1), pp. 131-136, https://doi.org/10.1016/i.jepes.2010.06.019

[33] Coello Coello, A. C.; Cortes, C. N., 2005: Solving Multiobjective Optimization Problems Using an Artificial Immune System, Genetic Programming and Evolvable Machines, 6 (2), pp. 163-190, https://doi.org/10.1007/s10710-005-6164-x

[34] Liao, G.-C. 2006: Short-term thermal generation scheduling using improved immune algorithm, Electric Power Systems Research, 76 (5) pp. 360-373, https://doi.org/10.1016/j.epsr.2005.06.009

[35] Huang, T.-L.; Hsiao, Y.-T.; Chang, C.-H.; Jiang, J.-A. 2008: Optimal placement of capacitors in distribution systems using an immune multi-objective algorithm, International Journal of Electrical Power \& Energy Systems, 30 (3), pp. 184-192, https://doi.org/10.1016/j.jjepes.2007.06.012

[36] Basu, M. 2012: Artificial immune system for combined heat and power economic dispatch, International Journal of Electrical Power \& Energy Systems, 43 (1), pp. 1-5, https://doi.org/10.1016/j.ijepes.2012.05.016

[37] Timmis, J.; Andrews, P.; Hart, E. 2010: Special issue on artificial immune systems, Swarm Intelligence, 4 (4), pp. 245-246, https://doi.org/10.1007/s11721-010-0047-3

[38] Omkar, N. S.; Khandelwal, R., Yathindra, S.; Naik, N. G.; Gopalakrishnan, S. 2008: Artificial immune system for multi-objective design optimization of composite structures, Engineering Applications of Artificial Intelligence, 21 (8), pp. 1416-1429, https://doi.org/10.1016/j.engappai.2008.01.002

[39] Tan, C. K.; Goh, K. C.; Mamun, A. A.; Ei, Z. E. 2008: An evolutionary artificial immune system for multiobjective optimization, European Journal of Operational Research, 187 (2), pp. 371-392, https://doi.org/10.1016/i.ejor.2007.02.047

[40] Sušanj, I. 2016: Development of the hydrological rainfall-runoff model based on artificial neural network in small catchments, PhD Thesis, Građevinski fakultet Rijeka (in Croatian)

[41] Obradović, D. 2018: A Short Review: Some Applications of Artificial Intelligence (Expert Systems and Neural Networks) in Hydrotechnics, 10 th Eastern European Young Water Professionals Conference, pp. 95-96.

Obradović, D 
[42] Mcculloch, S. W., Pitts, W. 1943: A logical calculus of the ideas immanent in nervous activity, The bulletin of mathematical biophysics, 5 (4), pp. 115-133, https://doi.org/10.1007/BF02478259

[43] Alavala, R. C. 2000: Fuzzy Logic and Neural Networks, Basic Concepts \& Applications, New Age International Publishers, New Delhi

[44] Rumelhart, D., Hinton, G., R. Williams, R. 1986: Learning representations by back-propagating errors, Nature 323, pp. 533-538, htps://doi.org/10.1038/323533a0

[45] Rabunal, R. J., Dorado, J. 2006: Artificial Neural Networks in Real-Life Applications, Idea Group Publishing, USA

[46] Fister, I.; Rauter, S.; Yang X.-S.; Ljubič, K.; Fister, I. Jr. 2015: Planning the sports training sessions with the bat algorithm, Neurocomputing, 149 (B), pp. 993-1002, https://doi.org/10.1016/j.neucom.2014.07.034

[47] Banzhaf, W.; Beslon, G.; Christensen, S.; Foster, A. J.; Képès, F.; Lefort, V.; Miller, F. J.; Radman, M.; Ramsden, J. J. 2006: Guidelines: from artificial evolution to computational evolution: a research agenda, Nature Reviews Genetics, 7 pp. 729-735, https://doi.org/10.1038/nrg1921

[48] Yang, X.-S. 2010: A new metaheuristic bat-inspired algorithm, in: Gonzalez, J. R. et al. (Eds.), Nature Inspired Cooperative Strategies for Optimization (NISCO 2010). Studies in Computational Intelligence, Springer Berlin, 284, Springer, Berlin, pp. 65-74, https://doi.org/10.1007/978-3-642-12538-6_6

[49] Gandomi, H. A.; Yang, X.-S. 2014: Chaotic bat algorithm, Journal of Computational Science, 5 (2), pp. 224232, https://doi.org/10.1016/j.jocs.2013.10.002

[50] Marchelvam, K. M.; Prabaharan, T., Yang, X.-S.; Geetha, M. 2013: Solving hybrid flow shop scheduling problems using bat algorithm, International Journal of Logistics, Economics and Globalisation, 5 (1), pp. 1529, https://doi.org/10.1504/IJLEG.2013.054428

[51] Yang, X. S. 2011: Bat algorithm for multiobjective optimization, International Journal of Bio-Inspired Computation, 3 (5), pp. 267-274, https://doi.org/10.1504/JJBIC.2011.042259

[52] Raghavan, S.; Marimuthu, C.; Sarwesh, P.; Chandresekaran, K. 2015: Bat algorithm for scheduling workflow applications in cloud, 2015 International Conference on Electronic Design, Computer Networks \& Automated Verification (EDCAV), Shillong, India, pp. 139-144, https://doi.org/10.1109/EDCAV.2015.7060555

[53] Hassanien, E. A.; Emary, E. 2016: Swarm intelligence, Principles, Advances, and Applications, Taylor \& Francis Group, Boca Raton

[54] Alihodžić, A.; Tuba, M. 2014: Improved Bat Algorithm Applied to Multilevel Image Thresholding, The Scientific World Journal, 2014, pp. 1-17, https://doi.org/10.1155/2014/176718

[55] Huang, G.-Q.; Zhao, W.-J.; Lu, Q.-Q. 2013: Bat algorithm with global convergence for solving large-scale optimization problem, Application Research of Computers, 30 (5), pp. 1323-1328, https://doi.org/10.1155/2014/176718

[56] Sonmez, M. 2011: Artificial Bee Colony algorithm for optimization of truss structures, Applied Soft Computing, 11 (2), pp. 2406-2418, https://doi.org/10.1016/j.asoc.2010.09.003

[57] Teodorović, D. 2003: Transport modeling by multi-agent systems: a swarm intelligence approach, Transportation Planning and Technology, 26 (4), pp. 289-312, https://doi.org/10.1080/0308106032000154593

[58] Lučić, P.; Teodorović. D. 2003: Computing with Bees: Attacking Complex Transportation Engineering Problems, International Journal on Artificial Intelligence Tools, 12 (3), pp. 375-394, https://doi.org/10.1142/S0218213003001289

[59] Nikolić, M.; Teodorović, D. 2013: Transit network design by Bee Colony Optimization, Expert Systems with Applications, 40 (15), pp. 5945-5955, https://doi.org/10.1016/j.eswa.2013.05.002

[60] Davidović, B. 2016: Modeliranje i odlučivanje u logističkim procesima, AGM knjiga, Beograd (in Serbian)

[61] Davidović, T.; Ramljak, D.; Šelmić, M.; Teodorović, D. 2011: Bee colony optimization for the p-center problem, Computer \& Operation Research, 38 (10), pp. 1367-1376, https://doi.org/10.1016/j.cor.2010.12.002

[62] Chalotra, S.; Sehra, K. S.; Sehra, S. S. 2016: A systematic review of applications of Bee Colony Optimization, 2016 International Conference on Innovation and Challenges in Cyber Security (ICICCS-INBUSH), Noida, India, pp. 257-260, https://doi.org/10.1109/ICICCS.2016.7542297

[63] Arabnejad, V.; Moeini, A.; Moghadam, N. 2011: Using Bee Colony Optimization to Solve the Task Scheduling Problem in Homogenous Systems, IJCSI International Journal of Computer Science Issues, 8 (5), pp. 348353.

Obradović, D 
[64] Karaboga, D.; Gorkemli, B.; Ozturk, C.; Karaboga, N. 2014: A comprehensive survey: artificial bee colony $(A B C)$ algorithm and applications, Artificial Intelligence Review, 42 (1), pp. 21-57, https://doi.org/10.1007/s10462-012-9328-0

[65] Sonmez, M. 2011: Discrete optimum design of truss structures using artificial bee colony algorithm, Structural and Multidisciplinary Optimization, 43 (1), pp. 85-97, https://doi.org/10.1007/s00158-010-0551-5

[66] Kwiecień, J.; Filipowicy, B. 2012: Firefly algorithm in optimization of queueing systems, Bulletin of the Polish academy of sciences, Technical sciences, 60 (2), pp. 363-368, https://doi.org/10.2478/v10175-012-0049-y

[67] Ali, N.; Othman, A. M.; Husain, N. M.; Misran, H. M. 2014: A review of firefly algorithm, ARPN Journal of Engineering and Applied Sciences, 9 (10), pp. 1732-1736

[68] Erdal, F. 2016: A firefly algorithm for optimum design of new-generation beams, Engineering Optimization, 49 (6), pp. 915-931, https://doi.org/10.1080/0305215X.2016.1218003

[69] Tong, N.; Fu, Q.; Zhong, C.; Wang, P. 2017: A mult-group firefly algorithm for numerical optimization, Journal of Physics: Conference Series, 887 (2017), https://doi.org/10.1088/1742-6596/887/1/012060

[70] Yang, X.-S. 2010: A new metaheuristic bat-inspired algorithm, Nature inspired cooperative strategies for optimization (NICSO 2010), Springer, pp. 65-74, https://doi.org/10.1007/978-3-642-12538-6_6

[71] Yang, X.-S. 2008: Nature-inspired metaheuristic algorithm, 2nd edition, University of Cambridge, United Kingdom, Luniver Press, England

[72] Yang, X.S.; He, X. 2013: Firefly algorithm: recent advances and applications, International Journal of Swarm Intelligence, 1 (1), pp. 36-50, https://doi.org/10.1504/IJSI.2013.055801

[73] Simpson, R. A.; Dandy, C. G.; Murphy, J. L. 1994: Genetic algorithms compared to other techniques for pipe optimization, Journal of Water Resources Planning and Management, 120 (4), pp. 423-443, https://doi.org/10.1061/(ASCE)0733-9496(1994)120:4(423)

[74] Jakobović, D.; Golub, M. 1999: Adaptive Genetic Algorithm, Journal of Computing and Information Technology, 7 (3), pp. 229-235, https://hrcak.srce.hr/150181, Accessed 5 May 2018

[75] Holland, J. H. 1975: Adaptation in natural and artificial systems: an introductory analysis with applications to biology, control, and artificial intelligence, Michigan Press

[76] Kannan, G.; Sasikumar, P.; Devika, K. 2010: A genetic algorithm approach for solving a closed loop supply chain model: A case of battery recycling, Applied Mathematical Modelling, 34 (3), pp. 655-670, https://doi.org/10.1016/j.apm.2009.06.021

[77] Diabat, A.; Kannan, D.; Kaliyan, M.; Svetinovic, D. 2013: An optimization model for product returns using genetic algorithms and artificial immune system, Resources, Conservation and Recycling, 74, pp. 156-169, https://doi.org/10.1016/j.resconrec.2012.12.010

[78] Mallawaarachchi, V. 2017: Introduction to Genetic Algorithms-Including Example Code, https://towardsdatascience.com/introduction-to-genetic-algorithms-including-example-code-e396e98d8bf3, Accessed 5 October 2018

[79] Cassar, R. l.; Titus, D. T.; Grill, M. W. 2017: An improved genetic algorithm for designing optimal temporal patterns of neural stimulation, Journal of Neural Engineering, 14 (6), pp. 1-14, https://doi.org/10.1088/17412552/aa8270

[80] Johanyák, C. Z. 2017: A modified particle swarm optimization algorithm for the optimization of a fuzzy classification subsystem in a series hybrid electric vehicle, Technical Gazette, 24 (suppl. 2), pp. 295-301, https://doi.org/10.17559/TV-20151021202802

[81] Praščević, N.; Praščević, Ž., 2014: Application of particle swarms for project time-cost optimization, Građevinar, 66 (12), pp. 1097-1107, https://doi.org/10.14256/JCE.1048.2014

[82] Kennedy, J.; Eberhart, R. 1995: Particle swarm optimization, Proceedings of ICNN'95 - International Conference on Neural Networks, 27 November - 1 December 1995, Perth, Australia, pp. 1942-1948, https://doi.org/10.1109//CNN.1995.488968

[83] Prathabrao, M.; Nawaei, A.; Sidek, N. A. 2017: Swarm size and iteration number effects to the performance of PSO algorithm in RFID tag coverage optimization, AIP Conference Proceedings, 1831 (1), https://doi.org/10.1063/1.4981192

[84] Peňa, E.; Zhang, S.; Deyo, S.; Xiao, Y.; Johnon, D. M. 2017: Particle swarm optimization for programming deep brain stimulation arrays, Journal of Neural Engineering, 14 (1), pp. 1-14, https://doi.org/10.1088/1741$\underline{\text { 2552/aa52d1 }}$

Obradović, D 
[85] PSO Tutorial, http://www.swarmintelligence.org/tutorials.php, Accessed 17 October 2018

[86] Kephart, O. J. 1994: A Biologically Inspired Immune System for Computers, In Artificial Life IV: Proceedings of the Fourth International Workshop on the Synthesis and Simulation of Living Systems, pp. 130-139.

[87] Chen, W. F.; Richard Liew, J. Y. (Eds.) 2003: The Civil Engineering Handbook, second edition, CRC Press, USA, available at: http://www.softouch.on.ca/kb/data/Civil\%20Engineering\%20Handbook\%20(2E).pdf, Accessed 28 November 2018

[88] What is civil engineering?, https://www.ice.org.uk/what-is-civil-engineering, Accessed 10 December 2018

[89] Afshar, M. H. 2010: A parameter free Continuous Ant Colony Optimization Algorithm for the optimal design of storm sewer networks: Constrained and unconstrained approach, Advances in Engineering Software, 41 (2), pp. 188-195, https://doi.org/10.1016/j.advengsoft.2009.09.009

[90] Christodoulou, A. S.; Ellinas, G. 2010: Pipe Routing through Ant Colony Optimization, Journal of Infrastructure Systems, 16 (2), pp. 149-159, https://doi.org/10.1061/(ASCE)1076-0342(2010)16:2(149)

[91] Kaveh, A.; Farahmand Azar, B.; Hadidi, A.; Rezezadeh Sorochi, F.; Talatahari, S. 2010: Performance-based seismic design of steel frames using ant colony optimization, Journal of Constructional Steel Research, 66 (4), pp. 566-574, https://doi.org/10.1016/j.jcsr.2009.11.006

[92] Kalinli, A.; Acar, C. M.; Gündüz, Z. 2011: New approaches to determine the ultimate bearing capacity of shallow foundations based on artificial neural networks and ant colony optimization, Engineering Geology, 177 (1-2), pp. 29-38, https://doi.org/10.1016/j.enggeo.2010.10.002

[93] Kalhor, E.; Khanzadi, M.; Eshtehardian, E.; Afshar, A. 2011: Stochastic time-cost optimization using nondominated archiving ant colony approach, Automation in Construction, 20 (8), pp. 1193-1203, https://doi.org/10.1016/. autcon.2011.05.003

[94] Zhang, Y.; Ng, T. S. 2012: An ant colony system based decision support system for construction time-cost optimization, Journal of Civil Engineering and Management, 18 (4), pp. 580-589, https://doi.org/10.3846/13923730.2012.704164

[95] Hashemi, S. S.; Tabesh, M.; Ataeekia, B. 2013: Ant-colony optimization of pumping schedule to minimize the energy cost using variable-speed pumps in water distribution networks, Urban Water Journal, 11 (5), pp. 335347, htps://doi.org/10.1080/1573062X.2013.795233

[96] Mobini, M.; Mobini, Z.; Rabbani, M. 2011: An Artificial Immune Algorithm for the project scheduling problem under resource constraints, Applied Soft Computing, 11 (2), pp. 1975-1982, https://doi.org/10.1016/j.asoc. 2010.06.013

[97] dos Anjos Lima, P. F.; Chavarette, F. R.; Frutuoso de Souza, S. S.; dos Santos e Souza, A.; Martins Lopes, M. L. 2014: Artificial Immune Systems Applied to the Analysis of Structural Integrity of a Building, Applied Mechanics and Materials, 472, pp. 544-549, https://doi.org/10.4028/www.scientific.net/AMM.472.544

[98] Zhang, J.; Hou, Z. 2014: Application of Artificial Immune System in Structural Health Monitoring, Journal of Structures, Article ID 709127, https://doi.org/10.1155/2014/709127

[99] Hola, B.; Schabowicz, K. 2010: Estimation of earthworks execution time cost by means of artificial neural networks, Automation in Construction, 19 (5), pp. 570-579, https://doi.org/10.1016/j.autcon.2010.02.004

[100] Li, J.; Dackermann, U.; Xu, L.-Y.; Samali, B. 2011: Damage identification in civil engineering structures utilizing PCA-compressed residual frequency response functions and neural network ensembles, Structural health and health monitoring, 18 (2), pp. 207-226, https://doi.org/10.1002/stc.369

[101] Kumar, R.; Aggarwal, R. K.; Sharma, J. D. 2013: Energy analysis of a building using artificial neural network: A review, Energy and Buildings, 65, pp. 352-358, https://doi.org/10.1016/j.enbuild.2013.06.007

[102] Heravi, G.; Eslamdoost, E. 2015: Applying Artificial Neural Networks for Measuring and Predicting Construction-Labor Productivity, Journal of Construction Engineering and Management, 141 (10), https://doi.org/10.1061/(ASCE)C0.1943-7862.0001006

[103] lštoka-Otković, I.; Varevac, D.; Šraml, M. 2015: Analysis of neural network responses in calibration of microsimulation traffic model, e-GFOS, 10, pp. 67-76, https://doi.org/10.13167/2015.10.8

[104] Zhou, Y.; Xie, J.; Zheng, H. 2013: A Hybrid Bat Algorithm with Path Relinking for Capacitated Vehicle Routing Problem, Mathematical Problems in Engineering, Article ID 392789, https://doi.org/10.1155/2013/392789

[105] Gholizadeh, S.; Amir Masoud Shahrezaei, A. M. 2014: Optimal placement of steel plate shear walls for steel frames by bat algorithm, The Structural Design of Tall and Special Buildings, 24 (1), pp. 1-18, https://doi.org/10.1002/tal.1151 
[106] Kaveh, A.; Zakian, P. 2014: Enhanced bat algorithm for optimal design of skeletal structures, Asian Journal of Civil Engineering, 115 (2), pp. 179-212.

[107] Talatahari, S.; Kaveh, A. 2015: Improved Bat Algorithm for Optimum Design of Large-scale Truss Structures, International Journal of Optimization in Civil Engineering, 5 (2) pp. 241-254, http://ijoce.iust.ac.ir/article-1-213en.html Accessed 28 November 2018

[108] Srichandum, S.; Rujirayanyong, T. 2010: Production Scheduling for Dispatching Ready Mixed Concrete Trucks Using Bee Colony Optimization, American Journal of Engineering and Applied Sciences 3 (1), pp. 7-14

[109] Pertiwi, A. P.; Suyanto, 2011: Globally Evolved Dynamic Bee Colony Optimization. In: König, A.; Dengel, A.; Hinkelmann, K.; Kise, K.: Howlett, R.J.; Jain, L.C. (eds.) Knowledge-Based and Intelligent Information and Engineering Systems. KES 2011. Lecture Notes in Computer Science, 6881, Springer, Berlin, Heidelberg, https://doi.org/10.1007/978-3-642-23851-2_6

[110] Kazemzadeh Azad, S; Kazemzadeh Azad, S. 2011: Optimum design of structures using an improved firefly algorithm, International Journal of Optimization in Civil Engineering, 1 (2), pp. 327-340, http://ijoce.iust.ac.ir/article-1-21-en.html, Accessed 28 November 2018

[111] Talatahari, S.; Gandomi, A. H.; Yun, G. J. 2012: Optimum design of tower structures using Firefly Algorithm, The Structural Design of Tall and Special Buildings, 23 (5), pp. 350-361, https://doi.org/10.1002/tal.1043

[112] Fleck Fadel Miguel, L.; Fleck Fadel Miguel, L. 2012: Shape and size optimization of truss structures considering dynamic constraints through modern metaheuristic algorithms, Expert Systems with Applications, 39 (10), pp. 9458-9467, https://doi.org/10.1016/j.eswa.2012.02.113

[113] Alqedra, M.; Arafa, M.; Ismail, M. 2011: Optimum Cost of Prestressed and Reinforced Concrete Beams using Genetic Algorithms, Journal of Artificial Intelligence, 4 (1), pp. 76-88, https://doi.org/10.3923/jai.2011.76.88

[114] Fan, S.-L.; Sun, K.-S.; Wang, Y.-R. 2012: GA optimization model for repetitive projects with soft logic, Automation in Construction, 21, pp. 253-261, https://doi.org/10.1016/j.autcon.2011.06.009

[115] Xie, H. S.; Yan, D. J.; Zheng, Y. Z. 2011: Optimization Design of High-Performance Concrete Based on Genetic Algorithm Toolbox of Matlab, Advanced Materials Research, 250-253, pp. 2672-2677, https://doi.org/10.4028/www.scientific. net/AMR.250-253.2672

[116] Aydin, Z:; Ayvaz, Y. 2013: Overall cost optimization of prestressed concrete bridge using genetic algorithm, KSCE Journal of Civil Engineering, 17 (4), pp. 769-776, https://doi.org/10.1007/s12205-013-0355-4

[117] Agrama, A. F. 2014: Mult-objective genetic optimization for scheduling a multi-storey building, Automation in Construction, 44, pp. 119-128, https://doi.org/10.1016/j.autcon.2014.04.005

[118] Faghihi, V.; Reinschmidt, F. K.; Kang, J. H. 2014: Construction scheduling using Genetic Algorithm based on Building Information Model, Expert Systems with Applications, 41 (16), pp. 7565-7578, https://doi.org/10.1016/j.eswa.2014.05.047

[119] Papadaki, I. N.; Chassiakos, A. P. 2016: Mult-objective Construction Site Layout Planning Using Genetic Algorithms, Procedia Engineering, 164, pp. 20-27, https://doi.org/10.1016/j.proeng.2016.11.587

[120] Gomes, H. M. 2011: Truss optimization with dynamic constraints using a particle swarm algorithm, Expert Systems with Applications, 38 (1), pp. 957-968, https://doi.org/10.1016/j.eswa.2010.07.086

[121] Nimtawata, P.; Nanakorn, P. 2011: Simple particle swarm optimization for solving beam-slab layout design problems, Procedia Engineering, 14, pp. 1392-1398, https://doi.org/10.1016/j.proeng.2011.07.175

[122] Doğan, E.; Saka, M. P. 2012: Optimum design of unbraced steel frames to LRFD-AISC using particle swarm optimization, Advances in Engineering Software, 46 (1), pp. 27-34, https://doi.org/10.1016/j.advengsoft.2011.05.008

[123] Chatterjee, S.; Sarkar, S.; Hore, S.; Dey, N.; Ashour, A. S.; Balas, E. V. 2017: Particle swarm optimization trained neural network for structural failure prediction of multistoried RC buildings, Neural Computing \& Applications, 28 (8), pp. 2005-2016, https://doi.org/10.1007/s00521-016-2190-2

Please cite this article as:

Obradović, D.: Review of nature-inspired optimization algorithms applied in civil engineering, Electronic Journal of the Faculty of Civil Engineering Osijek-e-GFOS, 2018, 17, pp. 74-88, htps://doi.org/10.13167/2018.17.8

Obradović, D 